\title{
般論文
}

\section{パーフルオロデカン酸をイオン交換基とした コロジオン膜の電気化学特性}

\author{
山内 昭*1, 永留 重実 ${ }^{* 2}$, 杉原 剛介*2 \\ * 1 九州大学理学部化学科 \\ 于812 福岡市東区箱崎 $6-10-1$ \\ * 2 福岡大学理学部化学科 \\ \%814-80 福岡市城南区七隈 8-19-1
}

(1994年 9 月 23 日受理)

\begin{abstract}
要 旨
コロジオン膜に炭化フッ素化合物であるパーフルオロデカン酸（PFDA）を含浸させた膜が キャスト法により作られた。この膜一電解質溶液系において膜電位, 流動電位, 膜伝導度を実 験的に求め, その結果に基づきこの膜のイオン交換特性を議論した。即ち, 膜電位から得られ る陽イオン輸率が 0.95 前後であることから膜内でPFDAが充分に解離し, 膜が陽イオン交換膜 として機能することが支持された。また膜伝導度についてドナン膜平衡の取り扱いを適用し膜 内の有効イオン交換基濃度を求めた。その結果, 膜伝導度が膜と平衡にある電解質濃度のみな らず膜内有効イオン基濃度にも強く依存することを示した。流動電位から得られる電気浸透係 数と有効イオン交換基濃度との関係を調べたこころ, ある含浸物濃度で電気浸透係数の急激な 増加を示し，その濃度以上での膜透過物性の変化が示唆された。
\end{abstract}

\section{1 はじめに}

イオン交換膜は通常強酸・強塩基型のスルホン 酸基や第 4 級アミノ基をイオン交換基としてもつ 高分子の三次元網目構造からなる，いわゆる高分 子荷電膜である。この種の荷電膜の最大の特徵は 溶液中の正・負イオンを電気的に分離することが できることである。1950年にその合成が発表され て以来 ${ }^{1)}$, 多くの研究者の注目を集め, その後, 研究開発·改良が精力的に進められ，現在では我々 の日常生活や化学工業界での様々な分野において このイオン交換膜は重要な存在として位置付けさ れている。例えば, 我が国の食卓塩は従来の塩田 法による製造が全面的に廃止され, 電気透析法に
よる海水濃縮から食塩を得ているが，その際の隔 膜として陽・陰イオン交換膜は中心的な役割を担 っている。また水銀法に替わる新しい苛性ソーダ 製造の際の電解隔膜として，このイオン交換膜は 不可欠なものとなっている。その他, 燃料電池に おける固体高分子電解質としてこの種の荷電膜の 利用やパルプ製造行程における廃水処理，アミノ 酸の分離・精製などその応用範囲はますます広が っている2, 3)。

一方，1970年代に入り， Nafion膜を中心とする 炭化フッ素系陽イオン交換膜の合成とその物性に 関する興味深い性質が報告されて以来，その基礎 的及び実用的な立場からの研究が盛んに行われて 
きた ${ }^{4-12)}$ 。一般にフッ素系イオン交換膜はテトラ フルオロエチレンを主鎖骨格とし，パーフルオロ エーテルの側鎖の末端にイオン基をもつ高分子荷 電膜である。この膜の特徵は従来の炭化水素系高 分子膜に比べて熱的及び化学的安定性に非常に優 れていることである。更に興味あることは膜内に 固定されたイオン交換基とその近傍の対イオンが 集まりクラスター構造を形成し，このクラスター が炭化フッ素マトリックス内に不均一に分散して いることが報告されている ${ }^{11,13)}$ 。これらの各クラ スターは細いチャンネルによってつながってお り,このような膜内の不均一構造がこの炭化フッ 素系荷電膜の特異的膜現象を惹起するもの之考え られている(3)。

以上の荷電膜に関する知識を背景にして我々は 新たな機能性をもつ荷電膜の研究・開発のため, モデル膜としてコロジオン膜に炭化フッ素系化合 物を含浸させた荷電膜のイオン交換性や電気化学 的特性を検討することにした。具体的には膜電位 や膜伝導度等の実験を通してこのイオン交換性を 物理化学的に吟味して行くことを本研究の目的と する。この膜を用いた実験系の利点としては含浸 物質の濃度を適当に変えることにより膜物性を調 節することができ，またコロジオンの強い疎水性 のため膜抵抗が通常の荷電膜に比べ大きく実験的 な立場からその測定が容易なことが挙げられる。 炭化フッ素系化合物としてイオン性界面活性剂で あるパーフルオロデカン酸（PFDA）を選んだ。こ の化合物が同じ炭素数をもつ炭化水素系に比べフ ッ素の強い電気陰性によるカルボン酸の解離性に 優れ，膜内固定イオン交換基としての働きが充分 期待される ${ }^{14,15)}$ 。

\section{2 実験}

\section{1 膜の調製及び測定セル}

コロジオン膜は分子量測定, 透析用, 写真感光 膜などに用いられる窒素含有量 10.5-12.5\%ニト ロセルロースからなる半透膜である。陽イオン交
換型コロジオン膜は $5 \%$ コロジオン・エーテル/エ タノール溶液に次に示したパーフルオロデカン酸 （PFDA）を加え，約 1 時間程超音波下での覞拌に より完全に溶解した後, その溶液 $2 \mathrm{ml}$ を直径 $5 \mathrm{~cm}$ のガラスシャーレにキャストし，調製した。

$\mathrm{CF}_{3}\left(\mathrm{CF}_{2}\right)_{8} \mathrm{COOH}$ (PFDA) 得られた膜は実験に使用する前少なくとも24時間 以上 $0.1 \mathrm{MKCl}$ 溶液に浸し, 膜を充分に溶液となじ

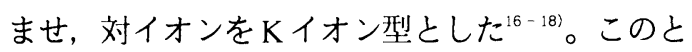
き膜から若干の PFDAの漏出が考えられる。しか し現時点ではその定量は行っておらず，従って以 下に用いる PFDA の含浸濃度はあくまでみかけの 濃度である。

この膜の断面を白金パラジュウム蒸着させて電 子顕微鏡写真による観測を行った。それによると 膜厚が約 $20 \mu \mathrm{m}$ で, 均一な層状構造をもつ膜であ ることを示した。

測定セルには各々 $20 \mathrm{~cm}^{3}$ の容積をもつガラスセ ルを用い, 膜はその 2 つセルの間に挟み, 膜の 有効面積は $\pi \mathrm{cm}^{2}$ とした。本実験では電解質水溶液 は全て $\mathrm{KCl}$ 水溶液を用いた。

\section{2 膜電位及び膜伝導度測定}

膜電位測定は膜の両側のガラスセル中に適当な 濃度の電解質水溶液 $(\mathrm{KCl})$ を置き, その膜一電解 質水溶液系に発生する濃淡電位をセルに固定した 一対の銀・塩化銀電極をデジタルポテンシオメー ターに接続して計测した。膜伝導度測定には膜電 位のときと同じようなガラスセルに白金黒電極を 固定し, 両水溶液相の電解質濃度を常に等しくし た系で，膜が有るときと無いときの系の伝導度を 測定し，その差の逆数を膜面積で除した值を膜伝 導度とした ${ }^{(9,21)}$ 。

\section{3 輸率}

一般に荷電膜一電解質水溶液系での膜内のイオン の輸率は Nernst の膜電位式により求めることがで きる。その膜電位式は外部電解質の活量の関数と 
して次のように与えられる。

$$
E_{m}=\left(2 t_{+}-1\right) \frac{R T}{z F} \ln \frac{a^{\text {II }}}{a^{1}}
$$

ここで $E_{\mathrm{m}}$ は現在の系で得られる膜電位,$\quad t_{+}$は膜内 陽イオンの輸率， $z$ はイオン価数，Fはファラディ 定数， $a^{\mathrm{I}} ， a^{\mathbb{1}}$ はそれぞれ外部水溶液相 (I)，（II） の電解質の活量である。この活量に文献值を代入 し実験的に得られた膜電位の值から陽イオン輸 率, $t_{+}$を求めた ${ }^{22)}$ 。

\section{4 流動電位}

膜を介してその両側に等濃度の電解質水溶液を 置いたとき発生する膜電位は零であるが，その一 片ッッカロースを添加すると浸透圧が生じ，そ

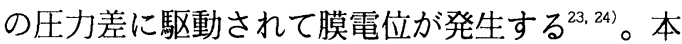
実験でのサッカロース濃度，0.25M，0.50M，

0.75M のときのVan't Hoff の式より求めた浸透圧 差はそれぞれ 6，12，18気圧であった。ここでは サッカロースを入れたとき $\left(E_{\mathrm{SA}}\right)$ と入れないとき $\left(E_{\mathrm{SA}-0}\right)$ の差を次のように表し, 膜を介した等濃度 電解質溶液系 $(\Delta C=0)$ における流動電位 $\Delta \varphi$ は この関係より求めた。

$$
\Delta \varphi=\left(E_{\mathrm{SA}}-E_{\mathrm{SA}=0}\right)_{\Delta \mathrm{C}=0}
$$

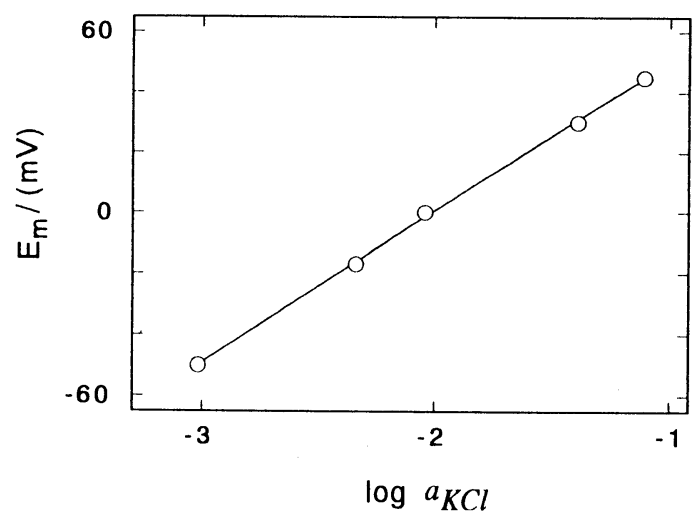

Fig.1 Relation between membrane potential, $E_{m}$ and activity of $\mathrm{KCl}$ in phase (II), log a $_{\mathrm{kcl}}$. PFDA concentration in membrane was fixed at $3 \mathrm{mM}$.

\section{3 結果及び考察}

\section{1 膜電位}

図 1 は膜電位測定結果の代表例である。荷電膜 は3mMPFDAのコロジオン溶液をキャストして作 ったもので，その膜を介し一方の外部 $\mathrm{KCl}$ 水溶液 相（I）の濃度を $10^{-2} \mathrm{M}$ に固定し他方の相（II）の $\mathrm{KCl}$ 濃度を $10^{-3} \mathrm{M}$ から $10^{-1} \mathrm{M}$ まで変化させたとき の膜電位をそこに示した。図からわかるように相 （II）の活量に対する膜電位は直線関係を与え，そ の勾配から調べられた濃度範囲における平均の陽 イオンの輸率， $t+t$ を(1) 式を用いて見積もること ができる。図 2 に異なる濃度の PFDA を含浸し た, すなわちカチオン交換基の濃度が異なる荷電 膜について求めた輸率， $t_{+}$を示した。結果は $t_{+}$の 值が 0.95 前後となっており, PFDAのカルボキシ ル基が充分に解離しイオン交換基としての機能を もつことを示した。市販の陽イオン交換膜と比べ るとその陽イオン選択性は若干劣るが陽イオン交 換膜としての機能をほぼ満足していると考えられ $3^{2)}$ 。一般に炭化水素系のカルボキシル基は中性 $\mathrm{pH}$ 領域では弱酸性型解離を示すが, 炭化フッ素系 のカルボキシル基はフッ素原子の強い電気陰性度 により水溶液中で強酸解離型となることが知られ ている ${ }^{14,15)}$ 。図 2 の結果から, 本研究のコロジオン 膜環境中においてもこのカルボキシル基は強酸型

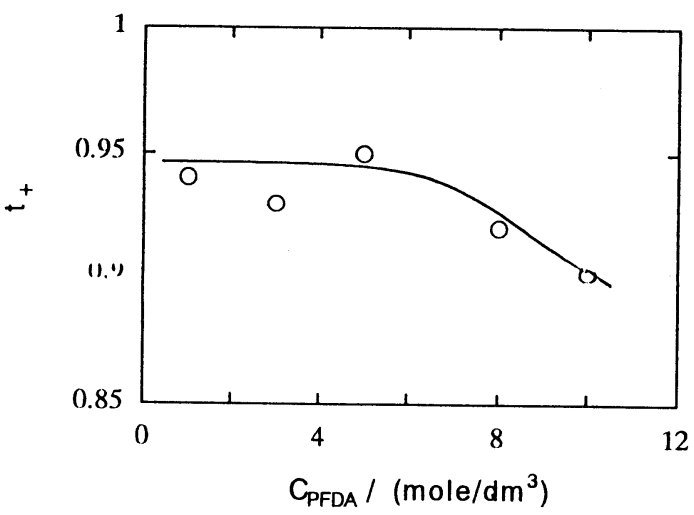

Fig.2 Cation transport numbers evaluated from Eq. (1) against collodion membranes containing different $\mathrm{C}_{\text {PFDA. }}$. 
解離を示し, 通常の強酸型陽イオン交換膜とほぼ 同等な挙動をすると考えられ, 大変興味深い。こ こで 1，3，5mM PFDA を含浸した膜より 8， $10 \mathrm{mM}$ PFDA を含浸した膜の輸率， $t_{+}$が小さい值 となっているのは後者の膜の選択性が劣ることを 意味している。これは PFDA 濃度増加によりカル ボキシル基間に反発が生じ, その膜内イオン交換 基間の間隔が多少広がりその結果として膜孔径が 増加し，そのためこの場合の副イオンである陰イ オンの透過が起こり, 若干選択性の低下に至った ものと思われる

\section{2 浸透圧勾配下における膜電位}

膜の片側にサッカロースを入れ浸透圧差を与え たときの膜電位と電解質の活量との関係を $3 \mathrm{mM}$ PFDA膜の場合について図3に示した。なお図中に は基準のためサッカロースを入れないときの膜電 位の結果も示した。（2）式に従って，KClの活量 が $10^{-2} \mathrm{M}$ におけるこの基準の膜電位との差を流動 電位として求めた。

一般に圧力を駆動力として発生する流動電位 $\Delta \varphi$ は次式により電気浸透係数， $\beta$ と関係づけられ $ろ^{23,24)}$ 。

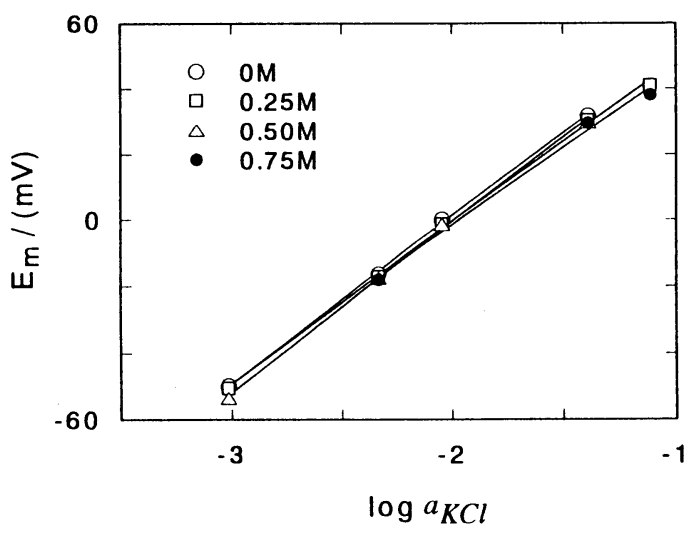

Fig.3 Membrane potential, $E_{m}$ under osmotic pressure difference. PFDA concentration in mem brane was fixed at $3 \mathrm{mM}$. Sucrose concentrations are inserted into figure.

$$
\beta=(\Delta \varphi / \Delta \Pi)_{I=0}
$$

ここで $\Delta$ Пは系にサッカロースを加えたとき生じ る浸透压差である。この（3）式を考慮すると，流 動電位と浸透圧差の比が電気浸透係数， $\beta$ となる。 この $\beta$ の物理的意味は次のSaxen の関数を考慮す ると理解しやす( ${ }^{23)}$ 。

$$
\beta=(\Delta \varphi / \Delta \Pi)_{I=0}=-(J / I)_{\Delta \varphi-0}
$$

ここでJ,Iはそれぞれ体積流と電流であるが, 換 言すると, 浸透圧勾配により駆動されたイオン流 束が系の電流，Iとなりそれに伴って移動する水の 量が $J$ なる。このことから オンによって運ばれる水の量を反映していること になる ${ }^{26,27)}$ 。この $\beta$ を異なるPFDA濃度の膜につい て示したのが図4である。この結果は（4）式を考 慮すると，4-5mM PFDA 濃度付近で何らかの急 激な膜内荷電構造変化によりイオン流束が増加し それに伴う水透過量の増加を示唆している。

\section{3 膜伝導度}

図 5 は実験のところで述べた方法により得られ る膜伝導度をPFDA の含浸濃度の異なる膜につい て調べた結果である。膜抵抗を求めるにあたっ

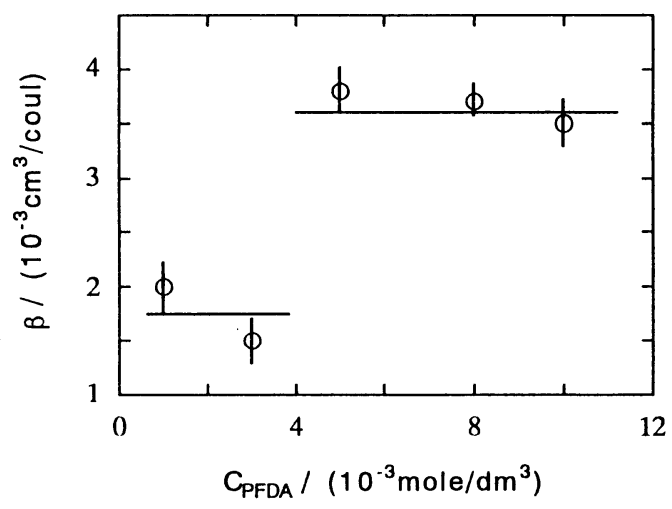

Fig.4 Relation between electroosmotic coefficient, $\beta$ and PFDA concentration in membrane. 


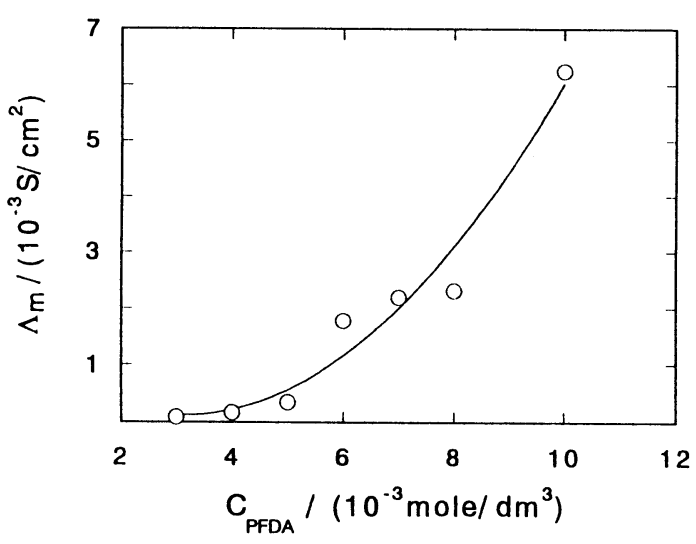

Fig.5 Relation between membrane conductance, $\Lambda_{m}$ and PFDA concentration in membrane. $\mathrm{KCl}$ concentrations in phases (I) and (II) were fixed at $10^{-2} \mathrm{M}$.

て，膜は $10^{-2} \mathrm{MKCl}$ 溶液と充分に平衡にさせた。 図から明らかなように膜内 PFDA 濃度の増加とと もに膜伝導度の増加が見られ, 特に $5 \mathrm{mM}$ 付近から 急激な膜伝導度の上昇を示した。更に5mM PFDA 含浸膜について, 膜と平衡にある外部 $\mathrm{KCl}$ 水溶液 濃度を変化させた場合の結果を図6に示した。こ の外部 $\mathrm{KCl}$ 水溶液の濃度依存性についても，ある $\mathrm{KCl}$ 濃度から急激な膜伝導度の増加が観测された。

これら膜伝導度の膜内濃度及び外部水溶液濃度 依存性に関して，この系は完全に平衡系と見做さ れドナン膜平衡による考察が可能であり，この考 えに基づき膜内有効イオン交換基濃度についての 検討を試みた ${ }^{28)}$ 。

現在の系のような 1-1 価型電解質の場合, 膜伝 導度 $\Lambda_{\mathrm{m}}$ は比伝導度 $\kappa$ と次のような関係にあり, 膜 内のイオン濃度 $\bar{C}_{+}, \bar{C}_{-}$とその移動度 $\bar{u}_{+}, \bar{u}_{-}$によ って与えられる。

$$
\Lambda_{m} l=\kappa=F\left(\bar{u}_{+} \bar{C}_{+}+\bar{u}_{-} \bar{C}_{-}\right)
$$

ここで $F$ とはそれぞれファラデー定数と膜厚であ る。膜内イオン濃度はドナン膜平衡式より外部電 解質濃度 Cの関数として得られ，それを上式に代 入すると $\mathrm{KCl}$ 溶液の場合, 次式を得る。

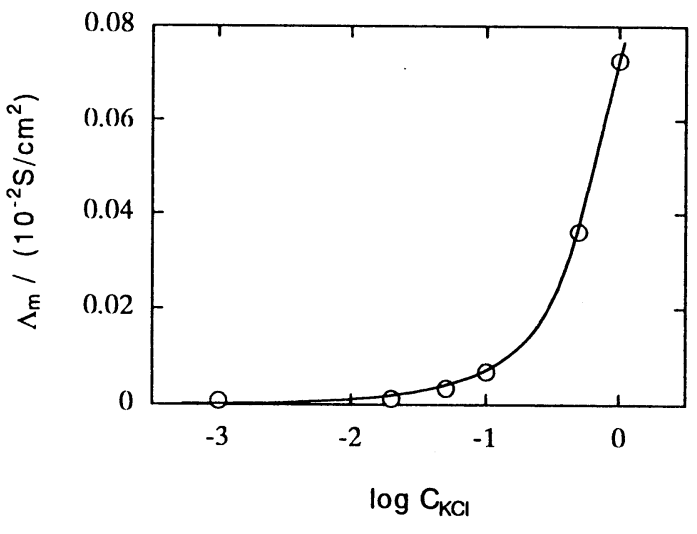

Fig.6 Dependence of membrane conductance, $\Lambda_{m}$ on outer $\mathrm{KCl}$ concentrations. PFDA concentration in membrane was fixed at $5 \mathrm{mM}$.

$$
\begin{aligned}
\Lambda_{m}= & F / l\left(\bar{u}_{K}+\bar{u}_{C l}\right)\left(1+\frac{X^{2}}{4 C^{2}}\right)^{1 / 2} C \\
& +F / 2 l\left(\bar{u}_{K}-\bar{u}_{C l}\right) X
\end{aligned}
$$

ここでXは膜内有効イオン交換基濃度で Cは外部 水溶液中の $\mathrm{KCl}$ の濃度, 添字 $\mathrm{K}, \mathrm{Cl}$ はそれぞれ $\mathrm{K}$ イオン, $\mathrm{Cl}$ イオンを表す。この（6）式によると膜 伝導度は膜厚と外部電解質濃度及び膜内有効イオ ン交換基濃度によって決まることになる。

図6の実験結果をこの（6）式で考えてみること にする。この系は一種類の膜, 即ち膜内含浸物の 濃度を固定した膜について外部溶液濃度を変えた 場合の実験であるので（6）式の右辺第2項は一定 值と仮定することは妥当であろう。特に外部溶液 が高濃度のときはいわゆるドナン塩効果により膜 伝導度などの膜物性は内部イオン交換基濃度に比 べ外部電解質濃度が断然支配的になることはよく 知られている。即ち, (6) 式右辺第一項中の $X^{2} /$ $4 C^{2}$ は 1 に比べて無視できることになる。これらを 考慮すると膜伝導度と外部電解質濃度との間には 次のような簡単な比例関係が成立する。

$$
\Lambda_{m}=\alpha C+\gamma
$$

ここで $\alpha$ と $\gamma$ は膜厚, 移動度, 膜内イオン交換基 


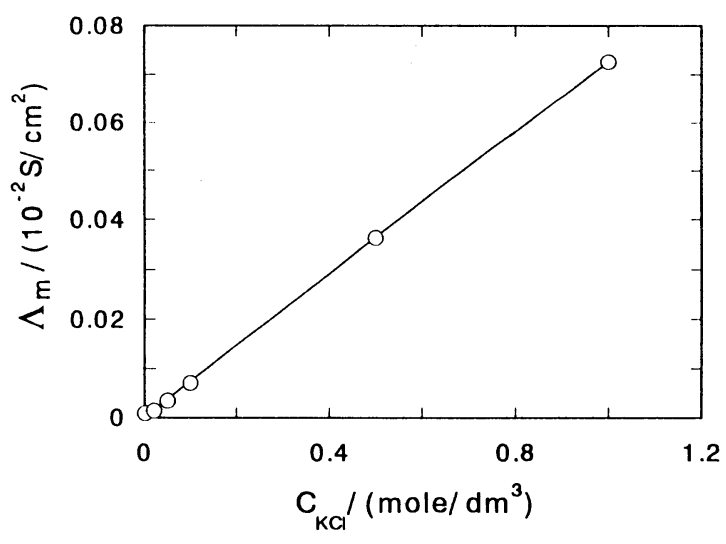

Fig.7 Relation between membrane conductance, $\Lambda_{\mathrm{m}}$ and $\mathrm{KCl}$ concentration obtained according to Eq. (7).

濃度等を含む一定值である。

図6の結果を（7）式に従ってプロットすると図 7に見られるように膜伝導度と外部 $\mathrm{KCl}$ 濃度との間 に良好な直線関係が得られた。その勾配 $\alpha$ から陽 イオンと陰イオンの移動度の和が得られ, これと 膜電位から得られた図 2 の輸率とから各イオンの 膜内での移動度を知ることができる。

膜内の移動度の值がわかると，（6）式に戻っ て，膜内イオン交換基濃度を変化させたときの膜 伝導度の結果を示す図 5 からその有効イオン交換 基濃度 $\mathrm{X}$ を求めることができる。図 8 に得られた 有効イオン交換基濃度 $\mathrm{X}$ に対する膜伝導度の值を 示したが，ここで注目すべき点はその関係が直線 的に変化することである。即ち，この結果は膜伝 導度が外部電解質濃度のみならず条件によっては 膜内イオン交換基濃度にも強く支配されることを 示している。ここで膜内有効イオン交換基濃度 X は膜内の含水量を基準としたモル濃度の単位とな っており，実験的な膜内含浸物質の濃度変化とは 直接関係がない。

以上のことから, 外部電解質濃度及び膜内含浸 物質濃度を変化させたときの膜伝導度は膜内ドナ ン塩濃度及び膜内有効イオン交換基濃度によって 大きく左右されることがわかった。更にこのとき

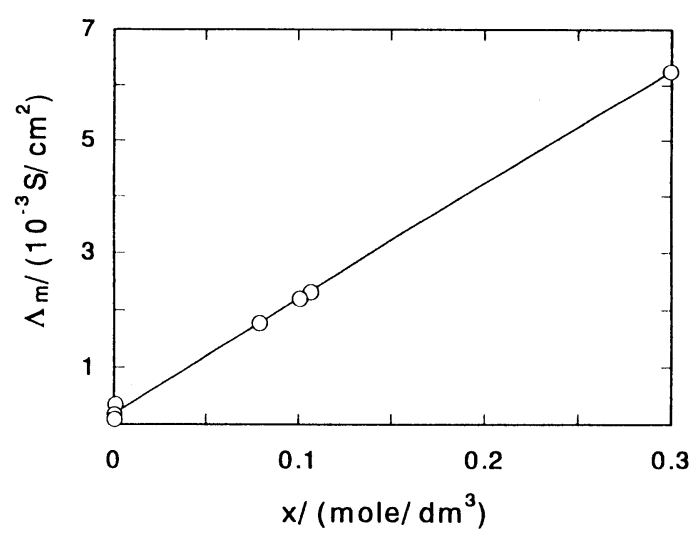

Fig.8 Membrane conductance, $\Lambda_{m}$ against effective concentration of ion exchange site, $X$.

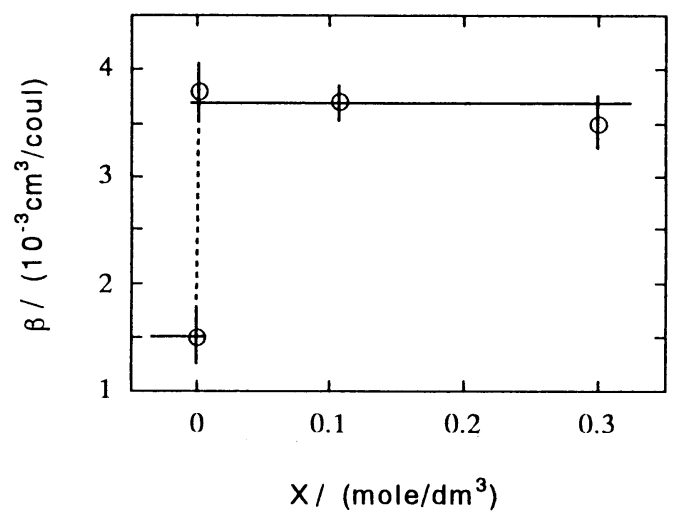

Fig.9 Electroosmotic coefficient, $\beta$ against effective concentration of ion exchange site, $X$.

膜内イオン移動度は予想したよりはるかに小さな 值となり，溶液中のそれより 100 倍以上小さ く29)，膜伝導度はむしろこの系では膜内イオン濃 度が支配的に影響しており，このことは（5）式に よって支持される。

\section{4 電気浸透係数， $\beta$ の再評価}

ここで得られた有効イオン交換基濃度によって 図 5 の電気浸透係数を再評価してみることは意義 あることと思われる。図9にその結果を示したが やはりイオン交換基濃度が極く低いところで急激 な $\beta$ の上昇が見られた。既に図4のところでも述 ベたように，コロジオン膜中に導入されたイオン 
交換基がその疎水的環境中で，ある濃度以上集ま るとイオン基間の反発が起こり, 膜孔径が少し広 がると考えられる ${ }^{25)}$ 。そこで塩としての透過が増 加し, 若干の輸率の低下となる。その際，水の移 動を伴いそれが電気浸透係数 $\beta$ の急激な上昇とな って現れたものと現在のところ考えている。しか しこの解釈はかなりの推量を含んでいるため, こ れらの点に関しては今後塩透過の測定など実験的 検討が必要であると考えている。

\section{謝辞}

本研究の一部は “財団法人ソルト・サイエンス 研究財団” の助成（No.9303）により行われた。著 者等はその援助に対し深く感謝の意を表します。

\section{文献}

1) W. Juda and W. A. McRase, J. Am. Chem. Soc., 72, 1044 (1950).

2）膜処理技術大系 (上,下巻), 中垣正幸 (監修), フジ ・テクノシステム (1991).

3）イオン交換膜の工業的応用 (第 2 集), 電気透析およ び膜分離技術研究会編，日本海水学会 (1993).

4) L. E. Chapman, Proceedings of the 7th Intersociety Conversion Engineering Conference, 466 (1972).

5) R. S. Yeo, J. McBreen, G. Kissel, F. Kulesa and S. Scrivasan, J. Appl. Electrochem., 10, 741 (1980).

6) H. Millsuer, Chem. Ing. Technol., 52, 53 (1980).

7) C. R. Martin and H. Freiser, Analyt. Chem., 53, 902 (1981).

8) D. Bergner, J. Appl. Electrochem., 12, 631 (1982).

9) T. D. Gierke, G. E. Mum and F. C. Wilson, J. Polym. Sci, Polym. Phys. Ed., 19, 1987 (1980).

10) S. C. Yeo and A. Eisenberg, J. Appl. Polym. Sci., 21, (1977).
11) W. Y. Hsu and T. D. Gierke, J. Memb. Sci., 13, 307 (1983).

12) P. C. Rieke and N. E. Vanderborgh, J. Memb. Sci., 32, 313 (1987).

13) M. L. Yeager, B. O Dell and Z. Twardowski, J. Electrochem. Soc., 139, 85 (1982).

14) K. Shinoda, T. Nakagawa, B. Tamamushi and T. Ise, "Colloidal Surfactants", Academic Press, New York (1963)

15）石川延男, 表面, 17, 693 (1979).

16) H. P. Gregor and K. Sollner, J. Phys. Chem., 50, 53 (1946).

17) K. Sollner and H. P. Gregor, J. Phys. Chem., 50, 470 (1946)

18) M. H. Gottlieb, R. Neihof and K. Sollner, J. Phys. Chem., 61, 154 (1957).

19) A. Yamauchi, M. Date, Y. Yamamoto, Y. Hirata and H. Kimizuka, Bull.Chem. Soc. Jpn., 61, 793 (1988).

20) Y. Hirata and A. Yamauchi, J. Memb. Sci., 48, 25 (1990).

21) A. Yamauchi, Y. Hirata and M. Shinoda, Desalination, 80, 61 (1991).

22) A. Yamauchi, Y. Okazaki, R. Kurosaki, Y. Hirata and H. Kimizuka, J. Memb. Sci., 32, 281 (1987).

23) A. Katchalsky and P. F. Curran, "Nonequilibrium Thermodynamics in Biophysics" Harvard University Press (1965).

24) A. Yamauchi and Y. Tanaka, "Effective Membrane Processes" Ed. by R. Paterson, BHR Group Limited, p. 179 (1993).

25）田村諭, 山崎隆喜, 田坂雅保, 高分子論文集, 34, 719 (1977).

26) 山内昭, 日本海水学会誌, 47, 224 (1993).

27) 山内昭, 材料科学, 30, 21 (1993).

28) S. G. Shultz, "Basic principles of membrane transport" Cambridge University Press (1980).

29）化学便覧, 基礎編 II, 日本化学会編 (1979). 


\title{
Electrochemical Characteristic of Collodion Membrane Containing Perfluorodecanoic Acid as Ion Exchange Site
}

\author{
Akira YAMAUCHI ${ }^{\circ 1}$, Shigemi NAGADOME ${ }^{\circ 2}$ and Gohsuke SUGIHARA ${ }^{\circ 2}$ \\ * 1 Department of Chemistry, Faculty of Science, Kyushu University \\ 6-10- 1 Hakozaki, Higashi-ku, Fukuoka 812, Japan \\ * 2 Department of Chemistry, Faculty of Science, Fukuoka University \\ 8-19-1 Nanakuma, Jonan-ku, Fukuoka 814-80, Japan
}

(Accepted September 23, 1994)

\begin{abstract}
Summary
Collodion based membranes containing perfluorodecanoic acid (PFDA) were made by cast method. In the membrane - aqueous electrolyte system, the membrane potential, streaming potential, and membrane conductance were measured and the ion exchange characteristic of the collodion membrane was examined. The cation transport numbers evaluated from the membrane potential indicated to be close to unity, and it suggested that the membranes behave as cation exchange membranes. The membrane conductances was analyzed by Donnan's membrane equilibrium and the effective concentration of ion exchange sites, $\mathrm{X}$ was estimated. As a result, the membrane conductance turned out to be strongly controlled by not only outer electrolyte concentration but also by the effective concentration of ion exchange site. The electroosmotic coefficient obtained from the streaming potential indicated the characteristic dependence on the effective concentration of ion exchange site, $\mathrm{X}$ and the correlation with water transport was discussed.
\end{abstract}

